\title{
REAKSI PASAR MODAL SEBELUM DAN SESUDAH PERISTIWA UPACARA PEMBUKAAN ASEAN GAMES 2018 DI JAKARTA
}

\author{
Sugeng Riyadi \\ Fakultas Ekonomi Jurusan Manajemen Universitas Semarang \\ Sugengrianto63@gmail.com \\ Sujito \\ Fakultas Ekonomi Jurusan Manajemen Universitas Semarang \\ ujit77777@gmail.com \\ Tri Rinawati \\ Fakultas Ekonomi Jurusan Manajemen Universitas Semarang \\ tri_rinawati@usm.ac.id
}

\begin{abstract}
The improvement of the capital market is impacted by a few capital market pointers, for example, capitalization esteems, the estimation of offers exchanged, and the stock value record. Changes from these factors will influence financial strength and political and security steadiness which mirror the dimension of certainty of monetary on-screen characters in household conditions, in this manner capital markets can influence the economy.

This investigation utilizes an occasion consider examination technique. The estimation time frame utilized amid the opening function of the Asian Games 2018 in Jakarta.

In this examination, the populace is all customer merchandise fabricating division organizations, nourishment and refreshment sub-segments on the Indonesia Stock Exchange (IDX). The examining system utilized immersed testing, which turned into the investigation test of 18 organizations. Specialized examination in the investigation utilizing an alternate test Paired Sample t-Test.

In view of the consequences of the distinction test, the Abnormal Return normal and Trading Average Activity Volume when the Asian Games 2018 are the equivalent (not unique).
\end{abstract}

Keywords: Abnormal Return, Trading Volume Activity, Asian Games 2018

\section{PENDAHULUAN}

\section{Latar Belakang Masalah}

Perkembangan pasar modal dipengaruhi oleh beberapa indikator pasar modal seperti nilai kapitalisasi, nilai saham yang ditransaksikan, dan indeks harga saham. Perubahan dari variable-variabel tersebut akan berpengaruh pada stabilitas perekonomian maupun stabilitas politik dan keamanan yang merefleksikan tingkat kepercayaan pelaku ekonomi terhadap kondisi domestik, oleh karena itu pasar modal dapat berpengaruh terhadap perekonomian. (Martalena dan Malinda, 2011)

Harga saham menurut Sartono (2008), bahwa harga saham terbentuk melalui mekanisme permintaan dan penawaran di pasar modal. Apabila suatu saham mengalami kelebihan permintaan, maka harga saham cenderung naik. Sebaliknya, apabila kelebihan penawaran maka harga saham cenderung turun.

Salah satu peristiwa yang terjadi di Indonesia yang mempengaruhi kondisi ekonomi Indonesia saat ini adalah penyelenggaraan Asian Games 2018 di Indonesia. Hal ini diperkirakan akan berkontribusi dalam mendorong pertumbuhan ekonomi. Bappenas memperkirakan, total dampak langsung dari perhelatan Asian Games 2018 sebesar Rp 45,1 triliun. Angka itu didapat baik dari sisi pengeluaran pengunjung, biaya konstruksi, dan biaya operasional, terhitung sejak 2015 hingga 2018. Dari sisi dampak langsung pengeluaran peserta dan pengunjung Asian Games 2018 diperkirakan mencapai Rp 3,6 triliun, dengan perincian pengeluaran sebesar Rp 2,5 triliun di Jakarta dengan konsentrasi persebaran peserta dan pengunjung sebanyak $70 \%$, dan $\mathrm{Rp} 1,1$ triliun di Palembang dengan konsentrasi persebaran peserta dan pengunjung sebanyak 30\%. (Movanita, 2018)

Asian Games diharapkan mampu menjadi stimulus positif bagi kinerja dan pergerakan sejumlah saham di sektor consumer goods. Asian Games akan menjadi trigger pendongkrak konsumsi masyarakat dan sektor consumer goods masih berpotensi tumbuh hingga akhir tahun yang secara sektoral masih overweight dengan outlook yang cukup positif. Kinerja saham-saham 
consumer goods turun tajam, secara year to date (ytd), indeks saham consumer goods sudah merosot 15,65\%, lebih buruk dibandingkan IHSG yang turun 7,77\% dari awal tahun hingga saat ini. Kinerja sektor ini berada di posisi dua terbawah di antara indeks sektoral Bursa Efek Indonesia (BEI). (Waluyo, 2018)

\section{Grafik 1. Pergerakan Harga saham Menjelang Asean Games 2018 Di Jakarta}

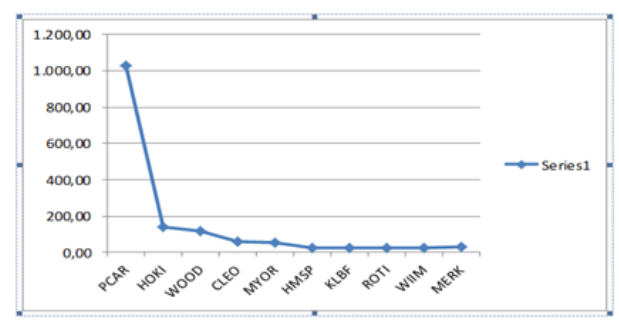

Sumber: www.kontan.co.id, 2018

Kenaikan sejumlah saham di sektor consumer goods dipengaruhi oleh beberapa faktor yang datang dari internal maupun eksternal. Salah satunya, beberapa saham consumer goods merupakan pendatang baru bursa atau baru saja melakukan IPO. Momen IPO ini membuat harga saham-saham tersebut masih murah sehingga banyak pelaku pasar, terutama para investor ritel, berlombalomba membeli saham ini karena harga sahamnya yang masih rendah. Untuk diketahui, PT Prima Cakrawala Abadi Tbk (PCAR) termasuk salah satu emiten pendatang baru di bursa yang baru IPO pada akhir Desember 2017. PT Buyung Poetra Sembada Tbk (HOKI) dan PT Integra Indocabinet Tbk (WOOD) baru melantai di pada pertengahan bulan Juni tahun lalu. Sedangkan PT Sariguna Primatirta Tbk (CLEO) menggelar IPO pada awal Mei tahun 2018. Di sisi lain, ada korelasi dengan faktor eksternal seperti penetrasi ekspor emiten seperti PT Integra Indocabinet Tbk (WOOD) yang cukup tinggi maupun naik penjualan Le Mineralle yang merupakan grup PT Mayora Indah Tbk (MYOR). (Waluyo, 2018)

Harga saham emiten consumer goods yang turun, hal tersebut disebabkan oleh efek pelemahan kurs rupiah terhadap dollar AS yang mempengaruhi struktur bisnis emiten consumer. Misalnya PT Kalbe Farma Tbk (KLBF) yang harus membayar biaya harga pokok penjualan yang lebih tinggi karena bahan bakunya berasal dari impor.
Emiten rokok juga mengalami penurunan laba operasi karena adanya penyesuaian tarif cukai sejak awal tahun lalu. Selain itu, ada juga sentimen eksternal seperti kenaikan The Fed Rate juga tentunya mempengaruhi emiten tersebut. Fundamental emiten consumer goods masih baik. Diperkirakan penjualan emiten akan mencapai target, tetapi bottom line akan ada efek penyesuaian biaya akibat naiknya rupiah ataupun naiknya tarif kebijakan pemerintah. (Waluyo, 2018)

Dua saham di sektor consumer goods yang dapat dilirik oleh investor seperti PT HM Sampoerna Tbk (HMSP) dan PT Indofood Sukses Makmur Tbk (INDF). Target harga PT HM Sampoerna Tbk (HMSP) di level Rp 4.200 per saham hingga akhir tahun. Sedangkan PT Indofood Sukses Makmur Tbk (INDF) diharapkan hingga akhir tahun bisa menyentuh level Rp 8.100 per saham. Pada akhir perdagangan hari Rabu tanggal 18 Juli 2018, harga saham PT HM Sampoerna Tbk (HMSP) turun 0,27\% ke level Rp 3.700 per saham. Sedangkan saham PT Indofood Sukses Makmur Tbk (INDF) juga turun 0,39\% ke level Rp 6.400 per saham. (Waluyo, 2018)

Hasil Penelitian yang dilakukan oleh Yuwono (2013), menunjukkan bahwa terdapat abnormal return positif pada saham yang bergerak di sektor consumer goods industry dan sub sektor retail di hari peristiwa. Abnormal return positif juga terjadi pada saat hari pertama, kedua, keempat, kelima, kedelapan dan kesepuluh. Uji perbedaan menunjukkan bahwa secara statistik terdapat perbedaan rata-rata abnormal return pada saham yang bergerak di sektor consumer goods industry dan sub sektor retail sebelum dan setelah peristiwa. Sedangkan untuk rata-rata aktivitas volume perdagangan saham tidak terdapat perbedaan yang signifikan secara statistik.

Adapun hasil penelitian yang dilakukan oleh Sari, Purnamawati dan Herawati (2017) menunjukkan bahwa rata-rata abnormal return selama periode peristiwa tidak terdapat perbedaan rata-rata abnormal return yang signifikan sebelum dan sesudah peristiwa pilpres Amerika Serikat 2016 dan rata-rata trading volume activity selama 
periode peristiwa, terdapat perbedaan rata-rata trading volume activity yang signifikan sebelum dan sesudah peristiwa pilpres Amerika Serikat 2016.

\section{Tinjauan Pustaka}

\section{Studi Peristiwa (Event Study)}

Studi peristiwa (event study) merupakan studi yang mempelajari reaksi pasar terhadap suatu peristiwa (event) yang informasinya dipublikasikan sebagai suatu pengumuman. Event study dapat digunakan untuk menguji kandungan informasi (information content) dari suatu pengumuman dan dapat juga digunakan untuk menguji efisiensi pasar bentuk setengah kuat (Jogiyanto, 2014).

\section{Pasar Modal}

Menurut Situmorang (2008), pasar modal adalah perdagangan instrumen keuangan (sekuritas) jangka panjang, baik dalam bentuk modal sendiri (stocks) maupun utang (bonds) baik yang diterbitkan oleh pemerintah maupun oleh perusahaan swasta. Adapun menurut Martalena dan Malinda (2011) pasar modal adalah pasar modal terdiri dari kata pasar dan modal, jadi pasar modal bisa didefinisikan sebagai tempat bertemunya permintaan dan penawaran terhadap modal; baik bentuk ekuitas maupun jangka panjang.

\section{Harga Saham}

Harga saham menentukan kekayaan pemegang saham. Maksimalisasi kekayaan pemegang saham diterjemahkan menjadi maksimalkan harga saham perusahaan. Harga saham pada satu waktu tertentu akan bergantung pada arus kas yang diharapkan diterima di masa depan oleh investor "rata-rata" jika investor membeli saham. (Brigham dan Houston, 2010

\section{Return Saham}

Return saham menurut Legiman (2015) merupakan hasil yang diperoleh dari investasi. Harapan untuk memperoleh return saham juga terjadi dalam asset financial. Suatu asset financial menunjukkan kesediaan investor menyediakan sejumlah dana pada saat ini untuk memperoleh sebuah aliran dana pada masa yang akan datang sebagai kompensasi atas faktor waktu selama dana ditanamkan dan risiko yang ditanggung. Dengan demikian para investor sedang mempertaruhkan suatu nilai sekarang untuk sebuah nilai yang diharapkan pada masa mendatang. Dalam konteks manajemen investasi, return atau tingkat keuntungan merupakan imbalan yang diperoleh dari investasi.

\section{Abnormal Return}

Jogiyanto (2014) mendefinisikan Abnormal Return adalah selisih return sesungguhnya yang terjadi dengan return ekspektasi. Sedangkan Suatu pengumuman yang mempunyai kandungan informasi akan memberikan abnormal return kepada pasar. Sebaliknya yang tidak mengandung informasi tidak memberikan abnormal return kepada pasar. Menurut Jogiyanto (2014), rumus untuk mengukur abnormal return adalah sebagai berikut:

$$
\begin{aligned}
& \quad \mathrm{RTN}_{\mathrm{i}, \mathrm{t}}=\mathrm{R}_{\mathrm{i}, \mathrm{t}}-\mathrm{E}\left(\mathrm{R}_{\mathrm{i}, \mathrm{t}}\right) \\
& \text { Dimana: } \\
& \mathrm{RTN}_{\mathrm{i}, \mathrm{t}}=\begin{array}{l}
\text { Retum tidak normal (abnormal retum) } \\
\text { sekuritas ke-i pada periode peristiwa ke-t }
\end{array} \\
& \mathrm{R}_{\mathrm{i}, \mathrm{t}}=\begin{array}{l}
\text { Retum sesungguhnya yang terjadi untuk } \\
\text { sekuritas ke-i pada periode peristiwa ke-t }
\end{array} \\
& \mathrm{E}\left(\mathrm{R}_{\mathrm{i}, t}\right)=\begin{array}{l}
\text { Retumn ekspektasi sekuritas ke-i pada periode } \\
\text { peristiwa ke-t }
\end{array}
\end{aligned}
$$

Sedangkan return sesungguhnya merupakan return yang terjadi pada waktu ke-t yang merupakan selisih harga sekarang relatif terhadap harga sebelumnya dan dapat dihitung dengan rumus sebagai berikut : (Jogiyanto, 2014)

$$
R_{i, t}=\left(P_{i, t}-P_{i, t,-1}\right) /\left(P_{i, t-1}\right)
$$

Dimana

$$
\begin{array}{ll}
P_{i, t} & =\text { Harga saham sekarang relatif } \\
P_{i,-1} & =\text { Harga saham sebelumnya } \\
\mathrm{R}_{i, t} & =\text { Return yang terjadi pada waktu ke-t }
\end{array}
$$

\section{Volume Perdagangan (Trading Volume Activity)}

Wismar'ien (2004), menyampaikan bahwa untuk mengukur TVA (Trading Volume Activity) dilakukan dengan membandingkan jumlah saham perusahaan yang diperdagangkan dalam suatu periode tertentu dengan keseluruhan jumlah saham beredar perusahaan tersebut pada kurun waktu yang sama, rumusnya sebagai berikut: TVA = Saham yang diperdagangkan pada waktu $\mathrm{t} /$ Saham yang beredar pada waktu t. Setelah TVA masingmasing saham diketahui, selanjutnya dihitung rata-rata 
TVA untuk periode di seputar tanggal peristiwa:

$$
\begin{array}{ll}
\qquad \text { XTVA }=\frac{\sum T V A_{i}}{N} \\
\text { Dimana: } \\
\text { XTVA }=\text { Rata-rata TVA pada waktu ket } \\
\text { TVAi } \quad \text { = TVA sekuritas I pada waktu ket } \\
\text { N } \quad \text { = Jumlah seluruh sampel yang diteliti }
\end{array}
$$

Membuat perbandingan secara statistik rata-rata TVA sebelum tanggal peristiwa dengan rata-rata TVA sesudah tanggal peristiwa untuk melihat apakah terdapat perbedaan yang signifikan secara statistik TVA diantara kedua periode tersebut.

\section{Penelitian Terdahulu}

Hasil Penelitian yang dilakukan oleh Yuwono (2013), menunjukkan bahwa terdapat abnormal return positif pada saham yang bergerak di sektor consumer goods industry dan sub sektor retail di hari peristiwa. Abnormal return positif juga terjadi pada saat hari pertama, kedua, keempat, kelima, kedelapan dan kesepuluh. Uji perbedaan menunjukkan bahwa secara statistik terdapat perbedaan rata-rata abnormal return pada saham yang bergerak di sektor consumer goods industry dan sub sektor retail sebelum dan setelah peristiwa. Sedangkan untuk rata-rata aktivitas volume perdagangan saham tidak terdapat perbedaan yang signifikan secara statistik.

Hasil Penelitian yang dilakukan oleh Sari, Purnamawati dan Herawati (2017) menunjukkan bahwa (1) Berdasarkan uji statistik terhadap rata-rata abnormal return selama periode peristiwa, ditemukan bahwa tidak terdapat perbedaan rata-rata abnormal return yang signifikan sebelum dan sesudah peristiwa pilpres Amerika Serikat 2016. (2) Berdasarkan uji statistik terhadap ratarata trading volume activity selama periode peristiwa, ditemukan bahwa terdapat perbedaan rata-rata trading volume activity yang signifikan sebelum dan sesudah peristiwa pilpres Amerika Serikat 2016.

Hasil Penelitian yang dilakukan oleh Octafilia (2016) menunjukkan abnormal return pada peristiwa Pemilihan, Pengumuman Hasil Pemilihan, dan Penetepan Hasil Pengumuman tidak signifikan. Abnormal return signifikan hanya ditunjukkan pada peristiwa Pelantikan
Presiden. Trading volume activity sebelum dan setelah keempat peristiwa juga menunjukkan tidak adanya perbedaan yang signifikan.

Hasil penelitian yang dilakukan oleh Purba dan Handayani (2017), berdasarkan hasil uji One Sample t-test menunjukkan bahwa terdapat abnormal return bernilai negatif signifikan pada satu hari di sekitar tanggal peristiwa, yang berarti bahwa pasar bereaksi terhadap peristiwa tersebut, namun hanya bersifat sesaat dan tidak berkepanjangan. Sedangkan hasil uji beda Paired Sample t-test menunjukkan bahwa tidak terdapat perbedaan yang signifikan antara Average Abnormal Return (AAR) sebelum dan sesudah peristiwa politik Pilkada DKI Jakarta 2017 Putaran Kedua. Hasil uji Wilcoxon Signed Rank Test juga menunjukkan bahwa tidak terdapat perbedaan signifikan antara Average Trading Volume Activity (ATVA) pada periode sebelum dan sesudah peristiwa politik Pilkada DKI Jakarta 2017 Putaran Kedua.

\section{Hubungan Logis Antar Variabel Dan Pengembangan Hipotesis}

a. Perbedaan Abnormal Return 6 hari sebelum Peristiwa Upacara Pembukaan Asean Games 2018 Di Jakarta tanggal 18 Agustus 2018

Hartono (2009) menjelaskan bahwa Abnormal return adalah return yang didapat investor yang tidak sesuai dengan pengharapan. Dengan kata lain Abnormal return adalah selisih antara return yang diharapkan (return ekspektasian) dengan return yang didapat. Selisih return akan positif jika return yang didapat lebih besar dari return yang diharapkan atau return yang dihitung. Sedangkan return akan negatif jika return yang didapat lebih kecil dari return yang diharapkan atau return yang dihitung. Abnormal return dapat terjadi karena adanya kejadian-kejadian tertentu, misalnya hari libur nasional, awal bulan, awal tahun, suasana politik yang tidak menentu, kejadian-kejadian yang luar biasa, stock split, penawaran perdana saham, dan lain-lain.

Berdasarkan hasil penelitian yang dilakukan oleh 
Purba dan Handayani (2017), menunjukkan bahwa terdapat abnormal return bernilai negatif signifikan pada satu hari di sekitar tanggal peristiwa, yang berarti bahwa pasar bereaksi terhadap peristiwa tersebut, namun hanya bersifat sesaat dan tidak berkepanjangan. Sedangkan hasil uji beda Paired Sample t-test menunjukkan bahwa tidak terdapat perbedaan yang signifikan antara Average Abnormal Return (AAR) sebelum dan sesudah peristiwa politik Pilkada DKI Jakarta 2017 Putaran Kedua.

Berdasarkan argumen tersebut di atas maka dapat dibangun hipotesis untuk penelitian sebagai berikut :

H1 : Terdapat perbedaan Abnormal Return 6 hari sebelum Peristiwa Upacara Pembukaan Asean Games 2018 Di Jakarta tanggal 18 Agustus 2018

b. Perbedaan Trading Volume Activity 6 hari sebelum Peristiwa Upacara Pembukaan Asean Games 2018 Di Jakarta tanggal 18 Agustus 2018

Volume perdagangan menurut Vibby (2010) adalah volume perdagangan mencerminkan perubahan harga dan dukungan terhadap nilai harga yang terjadi di pasar. Jadi, besarnya jumlah penawaran (supply) dan permintaan (demand) sangat mempengaruhi pergerakan bursa. Purba dan Handayani (2017) dalam penelitiannya menyimpulkan bahwa tidak terdapat perbedaan signifikan antara Average Trading Volume Activity (ATVA) pada periode sebelum dan sesudah peristiwa politik Pilkada DKI Jakarta 2017 Putaran Kedua.

Berdasarkan argumen tersebut di atas maka dapat dibangun hipotesis untuk penelitian sebagai berikut :

H2 : Terdapat perbedaan Trading Volume Activity 6 hari sebelum Peristiwa Upacara Pembukaan Asean Games 2018 Di Jakarta tanggal 18 Agustus 2018

c. Perbedaan Abnormal Return 6 hari sesudah Peristiwa Upacara Pembukaan Asean Games 2018

\section{Di Jakarta tanggal 18 Agustus 2018}

Definisi Abnormal Return menurut Husnan (2009), adalah selisih antara tingkat keuntungan sebenarnya dengan tingkat keuntungan yang diharapkan. Sedangkan Jogiyanto (2014) menjelaskan bahwa efisiensi pasar diuji dengan melihat return tidak normal (abnormal return) yang terjadi. Pasar dikatakan tidak efisien jika satu atau beberapa pelaku pasar dapat menikmati return tidak normal dalam jangka waktu yang cukup lama.

Hasil penelitian yang dilakukan oleh Purba dan Handayani (2017), menunjukkan bahwa terdapat abnormal return bernilai negatif signifikan pada satu hari di sekitar tanggal peristiwa, yang berarti bahwa pasar bereaksi terhadap peristiwa tersebut, namun hanya bersifat sesaat dan tidak berkepanjangan. Sedangkan hasil uji beda Paired Sample t-test menunjukkan bahwa tidak terdapat perbedaan yang signifikan antara Average Abnormal Return (AAR) sebelum dan sesudah peristiwa politik Pilkada DKI Jakarta 2017 Putaran Kedua. Hasil Penelitian yang dilakukan oleh Octafilia (2016) menunjukkan abnormal return pada peristiwa pemilihan, pengumuman hasil pemilihan, dan penetepan hasil pengumuman tidak signifikan. Abnormal return signifikan hanya ditunjukkan pada peristiwa Pelantikan Presiden.

Berdasarkan argumen tersebut di atas maka dapat dibangun hipotesis untuk penelitian sebagai berikut :

H3 : Terdapat perbedaan Abnornal Return 6 hari sesudah Peristiwa Upacara Pembukaan Asean Games 2018 Di Jakarta tanggal 18 Agustus 2018

\section{d. Perbedaan Trading Volume Activity 6 hari sesudah Peristiwa Upacara Pembukaan Asean} Games 2018 Di Jakarta tanggal 18 Agustus 2018

Sihombing (2009) memaparkan bahwa kegiatan perdagangan saham tidak berbeda dengan perdagangan pada umumnya yang melibatkan penjual dan pembeli, dari adanya perdagangan saham yang terjadi, maka akan menghasilkan volume perdagangan saham, ini menyebabkan jumlah transaksi saham atau volume saham yang diperjual belikan dapat berubah-ubah setiap hari.

Hasil penelitian yang dilakukan oleh Purba dan Handayani (2017), menunjukkan bahwa tidak terdapat perbedaan signifikan antara Average Trading Volume Activity (ATVA) pada periode sebelum dan sesudah peristiwa politik Pilkada DKI Jakarta 2017 Putaran Kedua. Hasil Penelitian yang dilakukan oleh Octafilia 
(2016), bahwa Trading volume activity sebelum dan setelah keempat peristiwa juga menunjukkan tidak adanya perbedaan yang signifikan.

Berdasarkan argumen tersebut di atas maka dapat dibangun hipotesis untuk penelitian sebagai berikut :

H4 : Terdapat perbedaan Trading Volume Activity 6 hari sesudah Peristiwa Upacara Pembukaan Asean Games 2018 Di Jakarta tanggal 18 Agustus 2018

\section{Gambar 1. Model Penelitian}

\begin{tabular}{|c|c|c|}
\hline $\begin{array}{c}\text { Abnormal Return } \\
6 \text { hari sebelum } \\
\text { Upacara } \\
\text { Pembukaan } \\
\text { Asean Games } \\
2018 \text { tanggal } 18 \\
\text { Agustus 2018 }\end{array}$ & & \begin{tabular}{|c} 
Abnormal Return \\
6 hari sesudah \\
Upacara \\
Pembukaan \\
Asean Games \\
2018 tanggal 18 \\
Agustus 2018 \\
\end{tabular} \\
\hline $\begin{array}{c}\text { Trading Volume } \\
\text { Activity } 6 \text { hari } \\
\text { sebelum Upacara } \\
\text { Pembukaan } \\
\text { Asean Games } \\
2018 \text { tanggal } 18 \\
\text { Agustus } 2018\end{array}$ & UJI BEDA & \begin{tabular}{|c|} 
Trading Volume \\
Activity 6 hari \\
sesudah Upacara \\
Pembukaan \\
Asean Games \\
2018 tanggal 18 \\
Agustus 2018 \\
\end{tabular} \\
\hline
\end{tabular}

\section{METODE}

\section{Jenis Penelitian}

Jenis penelitian yang digunakan adalah penelitian event study. Studi peristiwa (event study) merupakan study yang mempelajari reaksi pasar terhadap suatu peristiwa (event) yang informasinya dipublikasikan sebagai suatu pengumuman. (Jogiyanto, 2014). Langkah pertama yang dilakukan adalah menentukan periode penelitian. Periode estimasi yang digunakan adalah upacara pembukaan Asean Games 2018 di Jakarta pada tanggal 18 Agustus 2018.

\section{Jenis Dan Sumber Data}

Jenis data yang digunakan dalam penelitian ini adalah data sekunder. Data sekunder yang dibutuhkan adalah sebagai berikut : (1) Harga saham penutupan harian selama periode penelitian untuk tiap saham yang termasuk dalam daftar saham perusahaan manufaktur sektor industri consumer goods sub sektor makanan dan minuman; (2) Indeks saham perusahaan manufaktur sektor industri consumer goods sub sektor makanan dan minuman. Data diperoleh dari daftar perusahaan yang telah dipublikasikan di Bursa Efek Indonesia (www.idx.co.id).

\section{Populasi dan Sampel}

Arikunto (2013), memberikan pemahaman bahwa populasi adalah keseluruhan objek dalam penelitian, yang menjadi populasi dalam penelitian ini adalah semua sector consumer goods sub sektor makanan dan minuman di Bursa Efek Indonesia (BEI) yang berjumlah 47 perusahaan.

Teknik pengambilan sampel menggunakan purposive sampling, yang berarti bahwa teknik penentuan sampel menggunakan kriteria yang dipilih oleh peneliti. Adapun kriteria sebagai berikut : (1) Harga saham penutupan harian selama periode penelitian untuk tiap saham yang termasuk dalam daftar saham perusahaan manufaktur sektor consumer goods; (2) Perusahaan yang mempunyai volume saham dan value saham. Adapun perusahaan yang dapat dijadikan sampel sesuai dengan kriteria sebanyak 18 perusahaan, antara lain : BUDI, CAMP, CEKA, CLEO, GGRM, HMSP, HOKI, HRTA, IIKP, INAF, INDF, KAEF, KICI, KINO, KLBF, MYOR, PSDN, PYFA

\section{Definisi Operasional dan Pengukuran Variabel Penelitian}

\section{Abnormal Return}

Abnormal Return merupakan kelebihan dari return yang sesungguhnya terjadi terhadap return yang diharapkan atau dapat juga dikatakan bahwa abnormal return merupakan selisih antara return yang sesungguhnya terjadi dengan return ekspectasi. Abnormal Return diukur dengan menggunakan rumus sebagai berikut :

$\mathrm{AR}_{\mathrm{it}}=\mathrm{R}_{\mathrm{it}}-\mathrm{R}_{\mathrm{mt}}$

Keterangan :

$\mathrm{AR}_{\mathrm{it}}=$ Abnormal return saham i pada hari ke $-\mathrm{t}$

$\mathrm{R}_{\mathrm{it}} \quad=$ Actual return saham i pada hari $\mathrm{ke}-\mathrm{t}$

$\mathrm{R}_{\mathrm{mt}}=$ Expected return saham i pada hari ke $-\mathrm{t}$

\section{Trading Volume Activity}

Volume perdagangan saham merupakan jumlah saham yang diperdagangkan dalam periode tertentu. Volume perdagangan saham diukur dengan Trading Volume Activity (TVA) dengan membandingkan jumlah 
saham perusahaan yang beredar pada periode tertentu dengan jumlah saham yang beredar pada waktu tertentu. Setelah itu, rata-rata masing-masing volume perdagangan saham antara sebelum dan sesudah pemecahan saham dihitung untuk mengetahui besarnya perbedaan. Untuk mengetahui signifikan atau tidaknya digunakan uji beda dua rata-rata antara sebelum dan sesudah pemecahan saham. Adapun rumus yang digunakan yaitu (Husnan, 2009) :

$$
\text { TVA }=\frac{\text { Jumlah saham perusahaan i yang diperdagangkan pada waktu tertentu }}{\text { Jumlah saham perusahaan i yang beredar pada waktu tertentu }}
$$

Pada penelitian ini periode kejadian yang digunakan adalah selama dua belas hari, yang terdiri dari 6 hari sebelum peristiwa dan enam hari sesudah peristiwa upacara pembukaan Asean Games 2018 di Jakarta tanggal 18 Agustus 2018. Waktu enam hari ini diambil karena dianggap bahwa periode tersebut diharapkan dapat mencerminkan reaksi pasar. Jika periode peristiwa yang diambil terlalu singkat, maka dikhawatirkan adanya reaksi pasar yang cukup lama namun tidak dapat terdeteksi pada penelitian yang dilakukan. Sedangkan jika periode peristiwa yang diambil terlalu lama, dikhawatirkan adanya peristiwa lain yang cukup signifikan mempengaruhi hasil penelitiannya. Gambar periode waktu penelitian dapat dilihat pada gambar 3.1.

\section{Gambar 2. Periode waktu penelitian}

$\begin{array}{ccc} & & \\ \mathrm{t}-6 & \text { 18 Agustus 2017 } & \mathrm{t}+6 \\ \text { Estimation Period } & \text { Event Period } & \text { Estimation Period }\end{array}$

Alasan pengambilan periode penelitian (event period) $\mathrm{t}-6$ dan $\mathrm{t}+6$ adalah untuk menghindari counfounding effect akibat pengumuman stock split, merger, right issues atas peristiwa di luar peristiwa upacara pembukaan Asean Games 2018 di Jakarta tanggal 18 Agustus 2018.

\section{Teknik Analisis}

\section{Uji Statistik Deskriptif}

Soegiyono (2017) menjelaskan bahwa Statistik Deskriptif adalah statistik yang akan digunakan untuk menganalisis data dengan cara mendeskripsikan atau menggambarkan data yang telah terkumpul sebagaimana adanya tanpa bermaksud membuat kesimpulan yang berlaku umum atau generalisasi.

\section{Uji Normalitas}

Ghozali (2006) memberikan pemahaman bahwa uji normalitas bertujuan untuk menguji apakah terdapat nilai yang ekstrim yang menyebabkan hasil penelitian menjadi bias. Model regresi yang baik adalah memiliki distribusi data normal atau mendekati normal untuk mendeteksi normalitas dapat dilakukan dengan uji statistik. Test statistik yang digunakan untuk menguji nornalitas data adalah dengan menggunakan uji Kolmogorov Smirnov dengan kriteria pegujian sebagai berikut : a) Apabila nilai signifikan lebih besar dari 0,05 maka dapat disimpulkan bahwa data penelitian berdistribusi normal; b) Apabila nilai signifikan lebih kecil dari 0,05 maka dapat disimpulkan bahwa data penelitian berdistribusi tidak normal.

\section{Paired Sample $\mathbf{t}$ - Test}

Menurut Widiyanto (2013) paired sample t-test merupakan salah satu metode pengujian yang digunakan untuk mengkaji kefektifan perlakuan, ditandai adanya perbedaan rata-rata sebelum dan ratarata sesudah diberikan perlakuan. Dasar pengambilan keputusan untuk menerima atau menolak Ho pada uji paired sampel t-test adalah sebagai berikut : a) Jika probabilitas (Asymp.Sig) $<0,05$ maka Ho ditolak dan Ha diterima; b) Jika probabilitas (Asymp.Sig) > 0,05 maka Ho diterima dan Ha ditolak.

\section{HASIL DAN PEMBAHASAN \\ Hasil \\ Statistik Deskriptif}

Analisis deskriptif digunakan untuk memberikan gambaran mengenai variabel yang akan diteliti dan dilakukan dengan menggunakan nilai mean, nilai standard deviasi dan dan grafik.

Tabel 1. Deskripsi Variabel Abnormal Return

\begin{tabular}{|l|l|l|l|}
\hline & Sebelum & Sesudah & Pergerakan \\
\hline Abnormal Return & 0,005199634391 & 0,000761442495 & $(0,004438191896)$ \\
\hline
\end{tabular}

Berdasarkan hasil output tersebut, menunjukkan bahwa nilai Abnormal Return sebelum pelaksanaan Asean Games 2018 adalah sebesar 0,005199634391 dan menjadi 
Dinamika Sosial Budaya, Vol 21, No. 1, Juni 2019, pp 57-67

p-ISSN: 1410-9859\& e-ISSN: 2580-8524

http://journals.usm.ac.id/index.php/jdsb

sebesar 0,000761442495 setelah pelaksanaan Asean

Games 2018.

Gambar 3. Pergerakan Abnormal Return Sebelum dan Sesudah Pelaksanaan Asean Games 2018

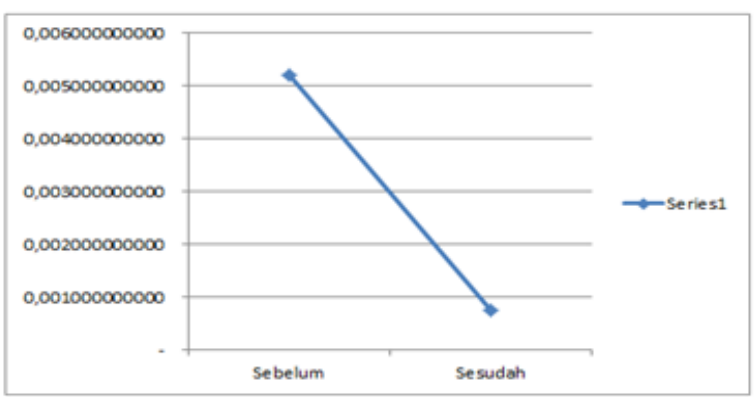

Berdasarkan grafik diatas, dapat dijelaskan bahwa nilai Abnormal Return mengalami penurunan $(0,004438191896)$ setelah pelaksanaan Asean Games 2018.

Tabel 2. Deskripsi Variabel Trading Volume Activity

\begin{tabular}{|c|c|c|c|}
\hline & Sebelum & Sesudah & Pergerakan \\
\hline TVA & 0,000688148470 & 0,000415515825 & $(0,000272632645)$ \\
\hline
\end{tabular}

Berdasarkan hasil output, menunjukkan bahwa nilai Trading Volume Activity sebelum pelaksanaan Asean Games 2018 adalah sebesar 0,000688148470 dan menjadi sebesar 0,000415515825 setelah pelaksanaan Asean Games 2018.

Gambar 4. Pergerakan Trading Volume Activity Sebelum dan Sesudah Pelaksanaan Asean Games 2018

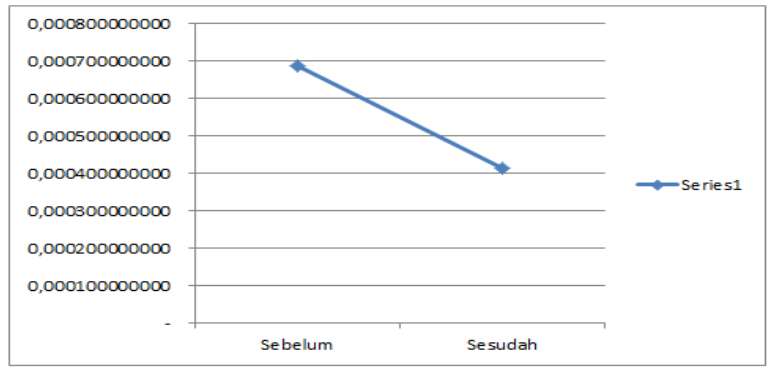

Berdasarkan grafik 5.2, dapat dijelaskan bahwa nilai Trading Volume Activity mengalami penurunan $(0,000272632645)$ setelah pelaksanaan Asean Games 2018.

Tabel 3. Hasil Uji Normalitas

\begin{tabular}{|ll|r|r|}
\hline & & \multicolumn{1}{|c|}{ Abnormal } & \multicolumn{1}{|c|}{ TVA } \\
\hline $\mathrm{N}$ & & 16 & 16 \\
& Mean &, 007551519923 &, 000551832147 \\
Normal Parameters ${ }^{\text {ab }}$ & & 41 & 66 \\
& Std. Deviation &, 012513030218 &, 000823062601 \\
& Absolute & 841 & 548 \\
& .273 & .259 \\
Most Extreme Differences & Positive & .266 & .259 \\
& Negative & .273 & -.251 \\
Kolmogorov-Smimov Z & & 1.092 & 1.036 \\
Asymp. Sig. (2-tailed) & & .184 & .233 \\
\hline
\end{tabular}

Berdasarkan output pada tabel, uji normalitas dengan menggunakan Uji Kolmogorov Smirnov menunjukkan bahwa nilai variabel Abnormal Return sebesar 0,233 dan Trading Volume Activity sebesar 0,184 lebih besar 0,05 sehingga dapat disimpulkan bahwa variabel Abnormal Return dan Trading Volume Activity berdistribusi normal.

\section{Paired Sample $\mathbf{t}$ - Test}

Tabel 4. Uji Paired Samples Statistics Abnormal Return

\begin{tabular}{|cc|c|c|c|c|}
\hline & & Mean & N & Std. Deviation & Std. Error Mean \\
\hline \multirow{2}{*}{ Pair 1 Abnormal_1 } &, 0082302180751 & 8 &, 016519408550747 &, 005840492903777 \\
& Abnormal_2 &, 0068728217717 & 8 &, 007847044647491 &, 0027743449241322 \\
\hline
\end{tabular}

Berdasarkan output hasil uji Paired Samples Statistics, menunjukkan bahwa rata-rata Abnormal Return pada saat sebelum dan sesudah pelaksanaan Asean Games 2018. Sebelum pelaksanaan Asean Games 2018 nilai Abnormal Return sebesar 0,008 sementara setelah pelaksanaan Asean Games 2018 sebesar 0,006.

Tabel 5. Uji Paired Samples Correlations Abnormal Return

\begin{tabular}{|c|c|c|c|}
\hline & $\mathrm{N}$ & Correlation & Sig. \\
\hline Pair 1 Abnomal_1 \& Abnomal_2 & 8 & .803 & .017 \\
\hline
\end{tabular}

Berdasarkan output hasil uji Paired Samples Correlations, menunjukkan bahwa korelasi antara dua variabel adalah sebesar 0,803 dengan signifikan sebesar 0,017 lebih kecil dari 0,05. Hal ini menunjukkan bahwa korelasi antara dua rata-rata Abnormal Return sebelum dan sesudah pelaksanaan Asean Games 2018 adalah kuat dan signifikan.

Tabel 6. Uji Paired Samples Test Abnormal Return 


\begin{tabular}{|c|c|c|c|c|c|c|c|c|}
\hline & \multicolumn{5}{|c|}{ Paired Differences } & \multirow{3}{*}{$\mathrm{t}$} & \multirow{3}{*}{\multicolumn{2}{|c|}{$\begin{array}{l}\text { Sig. } \\
(2- \\
\text { taile } \\
\text { d) }\end{array}$}} \\
\hline & \multirow[t]{2}{*}{ Mean } & \multirow[t]{2}{*}{$\begin{array}{l}\text { Std. } \\
\text { Deviation }\end{array}$} & \multirow[t]{2}{*}{$\begin{array}{l}\text { Std. Error } \\
\text { Mean }\end{array}$} & \multicolumn{2}{|c|}{$\begin{array}{l}95 \% \text { Confidence } \\
\text { Interval of the } \\
\text { Difference }\end{array}$} & & & \\
\hline & & & & Lower & Upper & & & \\
\hline \begin{tabular}{|ll} 
Pair & Abnormal_1- \\
1 & Abnormal _2 \\
\end{tabular} & ,0013573 &, 0112430 & ,0039750 & ;,0080419 & ,0107567 & .341 & 7 & .743 \\
\hline
\end{tabular}

Hipotesis yang akan diajukan adalah Ho : rata-rata Abnormal Return adalah sama dan $\mathrm{H} 1$ : rata-rata Abnormal Return adalah berbeda. Berdasarkan output hasil uji Paired Samples Test, nilai t hitung sebesar 0,341 dengan nilai signifikan 0,743 lebih besar 0,05, sehingga dapat disimpulkan bahwa Ho diterima yang artinya ratarata Abnormal Return sebelum dan sesudah pelaksanaan Asean Games 2018 adalah sama (tidak berbeda). Hal ini dapat dinyatakan bahwa pelaksanaan Asean Games 2018 tidak mempengaruhi pergerakan saham (Abnormal Return) pada perusahaan manufaktur sektor consumer goods untuk sub sektor makanan dan minuman.

\section{Tabel 7. Uji Paired Samples Statistics Trading Volume} Activity

\begin{tabular}{|cc|c|c|c|c|}
\hline & & Mean & N & Std. Deviation & Std. Error Mean \\
\hline \multirow{2}{*}{ Pair 1 } & TVA_1 &, 00068814847023 & 8 &, 001033675436635 &, 000365459455460 \\
& TVA_2 &, 00041551582510 & 8 &, 000583679473677 &, 000206361857003 \\
\hline
\end{tabular}

Berdasarkan output hasil uji Paired Samples Statistics, menunjukkan bahwa rata-rata Trading Volume Activity pada saat sebelum dan sesudah pelaksanaan Asean Games 2018. Sebelum pelaksanaan Asian Games 2018 nilai Trading Volume Activity sebesar 0,0006 sementara setelah pelaksanaan Asian Games 2018 sebesar 0,0004

Tabel 8. Uji Paired Samples Correlations Trading Volume Activity

\begin{tabular}{|ll|r|r|r|}
\hline & \multicolumn{1}{|c|}{ N } & Correlation & Sig. \\
\hline Pair 1 TVA_1 \& TVA_2 & & 8 & .963 & .000 \\
\hline
\end{tabular}

Berdasarkan output hasil uji Paired Samples Correlations, menunjukkan bahwa korelasi antara dua variable adalah sebesar 0,963 dengan signifikan sebesar 0,000 lebih kecil dari 0,05. Hal ini menunjukkan bahwa korelasi antara dua rata-rata Trading Volume Activity sebelum dan sesudah pelaksanaan Asean Games 2018 adalah kuat dan signifikan.
Tabel 9. Uji Paired Samples Test Trading Volume Activity

\begin{tabular}{|c|c|c|c|c|c|c|c|c|}
\hline & & & ired Differenc & & & & & \\
\hline & Mean & $\begin{array}{c}\text { Std. } \\
\text { Deviation }\end{array}$ & $\begin{array}{c}\text { Std. Error } \\
\text { Mean }\end{array}$ & $\begin{array}{l}95 \% \text { Con } \\
\text { Interval } \\
\text { Diffe }\end{array}$ & $\begin{array}{l}\text { fifidence } \\
\text { of the } \\
\text { rence }\end{array}$ & $\mathrm{t}$ & df & $\begin{array}{l}\text { Sig. } \\
\text { (2. } \\
\text { tailed) }\end{array}$ \\
\hline & & & & Lower & Upper & & & \\
\hline Pair 1 TVA 1 - TVA 2 &, 0002726 &, 0004971 &, 0001757 &,- 0001429 & 00068822 & 1.551 & & $\theta$ \\
\hline
\end{tabular}

Hipotesis yang akan diajukan adalah Ho : rata-rata Trading Volume Activity adalah sama dan H1 : rata-rata Trading Volume Activity adalah berbeda. Berdasarkan output hasil uji Paired Samples Test, nilai t hitung sebesar 1,551 dengan nilai signifikan 0,165 lebih besar 0,05, sehingga dapat disimpulkan bahwa Ho diterima yang artinya rata-rata Trading Volume Activity sebelum dan sesudah pelaksanaan Asian Games 2018 adalah sama (tidak berbeda). Hal ini dapat dinyatakan bahwa pelaksanaan Asian Games 2018 tidak mempengaruhi pergerakan Trading Volume Activity pada perusahaan manufaktur sektor consumer goods untuk sub sektor makanan dan minuman.

\section{Pembahasan}

\section{Perbedaan Abnormal Return Sebelum dan Sesudah}

\section{Pelaksanaan Asean Games 2018}

Berdasarkan hasil uji perbedaan, rata-rata Abnormal Return sebelum dan sesudah pelaksanaan Asean Games 2018 adalah sama (tidak berbeda) artinya pelaksanaan Asean Games 2018 tidak mempengaruhi pergerakan saham (Abnormal Return) pada perusahaan manufaktur sektor consumer goods untuk sub sektor makanan dan minuman

Hasil penelitian ini didukung oleh teori Jogiyanto (2014) bahwa suatu pengumuman yang mempunyai kandungan informasi akan memberikan abnormal return kepada pasar, sebaliknya yang tidak mengandung informasi tidak memberikan abnormal return kepada pasar.

Hasil penelitian ini didukung oleh penelitian yang dilakukan oleh Sari, Purnamawati dan Herawati (2017), Octafilia (2016), dan Purba dan Handayani (2017) yang menyatakan bahwa rata-rata abnormal return selama periode peristiwa, ditemukan bahwa tidak terdapat perbedaan rata-rata abnormal return yang signifikan 
Dinamika Sosial Budaya, Vol 21, No. 1, Juni 2019, pp 57-67

p-ISSN: 1410-9859\& e-ISSN: 2580-8524

http://journals.usm.ac.id/index.php/jdsb

sebelum dan sesudah peristiwa.

\section{Perbedaan Trading Volume Activity Sebelum dan}

\section{Sesudah Pelaksanaan Asean Games 2018}

Berdasarkan hasil uji perbedaan, rata-rata Trading Volume Activity sebelum dan sesudah pelaksanaan Asean Games 2018 adalah sama (tidak berbeda) artinya pelaksanaan Asean Games 2018 tidak mempengaruhi pergerakan Trading Volume Activity pada perusahaan manufaktur sektor consumer goods untuk sub sektor makanan dan minuman.

Hasil penelitian ini didukung oleh teori Wismar'ien (2004), bahwa jumlah saham perusahaan yang diperdagangkan dalam suatu periode tertentu dengan keseluruhan jumlah saham beredar perusahaan tersebut pada kurun waktu yang sama, yang pergerakannya tidak dipengaruhi oleh peristiwa.

Hasil penelitian ini didukung oleh penelitian yang dilakukan oleh Octafilia (2016) dan Purba dan Handayani (2017), yang menyatakan bahwa tidak terdapat perbedaan signifikan antara rata-rata Trading Volume Activity sebelum dan sesudah peristiwa.

\section{KESIMPULAN}

Berdasarkan hasil uji perbedaan, rata-rata Abnormal Return sebelum dan sesudah pelaksanaan Asean Games 2018 adalah sama (tidak berbeda) artinya pelaksanaan Asian Games 2018 tidak mempengaruhi pergerakan saham (Abnormal Return) pada perusahaan manufaktur sektor consumer goods untuk sub sektor makanan dan minuman.

Berdasarkan hasil uji perbedaan, rata-rata Trading Volume Activity sebelum dan sesudah pelaksanaan Asian Games 2018 adalah sama (tidak berbeda) artinya pelaksanaan Asian Games 2018 tidak mempengaruhi pergerakan Trading Volume Activity pada perusahaan manufaktur sektor consumer goods untuk sub sektor makanan dan minuman.

\section{Implikasi Teoritis}

Penelitian mengenai perbedaan rata-rata Abnormal Return dan rata-rata Trading Volume Activity pada saat bertepatan dengan sebelum dan sesudah pelaksanaan Asean Games 2018 adalah tidak terdapat perbedaan. Namun pertumbuhan ekonomi kaitannya dengan peaksanaan Asean games 2018 justru diperkirakan akan ada peningkatan di atas 10 persen dan membuat pasar modal Indonesia menjadi semakin baik, begitu juga akan mempengaruhi menguatnya rupiah. Hal ini akan membawa dampak positif bagi perekonomian Indonesia.

Hasil penelitian event study tentang pelaksanaan Asean Games 2018 ini didukung oleh penelitian yang dilakukan oleh Sari, Purnamawati dan Herawati (2017), Octafilia (2016), dan Purba dan Handayani (2017) yang menyatakan bahwa rata-rata abnormal return rata-rata Trading Volume Activity tidak terdapat perbedaan yang signifikan sebelum dan sesudah peristiwa pelaksanaan Asean Games 2018.

\section{Implikasi Praktis}

Asean Games 2018 diperkirakan mempengaruhi nilai investasi, Indeks Harga Saham Gabungan (IHSG), nilai rupiah dan nilai kegiatan ekonomi. Berikut ini implikasi kebijakan penelitian yang berkaitan dengan informasi pelaksanaan Asean Games 2018 :

a. Investor : Secara teknikal, kenaikan ISHG masih berlanjut, hal ini dikarenakan ada beberapa sentiment positif dari beberapa saham yang memiliki laporan keuangan tahun 2018 yang bagus dengan profit atau keuntungan yang baik. Secara umum keadaan indeks dibantu dengan pergerakan nilai mata uang yang stabil serta ekspektasi Asian Games 2018 yang sedang berjalan menjadi sentiman positif bagi pasar modal.

b. Pemerintah : IHSG pada akhir pelaksanaan Asean Games 2018 sedikit mengalami pull back. Sentimen penyumbangnya adalah anggaran infrastruktur yang dinaikkan, dikeluarkannya paket kebijakan pemerintah untuk meningkatkan daya beli masyarakat. IHSG cukup dipengaruhi dengan adanya pergerakan rupiah yang cenderung stabil dan juga dari sentimen dalam negeri yang menurutnya tidak berpengaruh signifikan, tapi cukup mampu mendongkrak pasar. 


\section{Keterbatasan Penelitian}

1. Pergerakan saham menjelang pelaksanaan maupun setelah pelaksanaan Asean Games 2018 mengalami fluktuatif, menyebabkan sikap menunggu bagi investor karena pergerakan harga saham sulit untuk diamati.

2. Periode waktu pengamatan selama penelitian ini menggunakan periode waktu pengamatan 6 hari sebelum dan 6 hari sesudah pelaksanaan Asean Games 2018, adapun untuk memprediksi pergerakan saham membutuhkan waktu yang panjang agar memperoleh hasil yang lebih akurat dalam memprediksi perbedaan pergerakan saham sebelum dan sesudah peristiwa.

\section{DAFTAR PUSTAKA}

Ahmad, K. (2004). Dasar-dasar Manajemen Investasi dan Portopolio. Jakarta: Rineka Cipta.

Arikunto, S. (2013). Prosedur Penelitian: Suatu Pendekatan Praktik. Jakarta: Rineka Cipta.

Ghozali, I. (2006). Aplikasi Analisis Multivariate Dengan Program SPSS. Cetakan Keempat. Semarang: Badan Penerbit Universitas Diponegoro.

Houston, B. d. (2010). Dasar-dasar Manajemen Keuangan. Buku 1. Edisi 11. Jakarta: Salemba Empat.

Husnan, S. (2009). Dasar-dasar Teori Portopolio \& Analisis Sekuritas. Yogyakarta: UPP STIM YKPN.

Ibrahim Sihombing, L. (2009). Pengaruh Inflasi, Kurs, Investasi, dan Suku Bunga Sertifikat Bank Indonesia (SBI) Terhadap Harga Saham dan Volume Perdagangan saham PT Bank Rakyat Indonesia (Tbk) Di Bursa Efek Indonesia.

Jogiyanto. (2014). Teori Portopolio dan Analisis Investasi. Edisi 10. Yogyakarta: BPFE.

Legiman, Fachreza Muhammad, \& et al. (2015). Faktorfaktor Yang Mempengaruhi Return Saham Pada Perusahaan Agroindustry Yang Terdaftar Di Bursa Efek indonesia Periode 2019-2012. Jurnal EMBA Vol. 3 No.3.

Mahrofi, Rubi. 2018. BEI: IHSG sepekan meningkat 1,98 persen. www.wartaekonomi.co.id. Diakses pada tanggal 29 Juli 2018

Martalena, dan Malinda. 2011. Pengantar Pasar Modal. Edisi Pertama. Yogyakarta : Andi.

Movanita, Ambaranie Nadia Kemala. 2018. Dampak Ekonomi Asian Games ke Ekonom Indonesia Capai $R p 45$ Triliun. www.kompas.com. Diakses pada tanggal 31 Mei 2018
Octafilia, Yusnita. 2016. Dampak Pemilihan Presiden Republik Indonesia Tahun 2014 Terhadap Abnormal Return Dan Trading Volume Activity Bursa Efek Indonesia (Even Studi Pada Saham Indeks Kompas 100). KURS Vol. 1 No. 1, Juni 2016. e-ISSN $2527-$ 8215

Purba, Fransisko dan Siti Ragil Handayani. 2017. Analisis Perbedaan Reaksi Pasar Modal Indonesia Sebelum Dan Sesudah Peristiwa Non Ekonomi (Studi pada Peristiwa Politik Pilkada DKI Jakarta 2017 Putaran Kedua). Jurnal Administrasi Bisnis (JAB) | Vol. 51 $\begin{array}{llll}\text { No. } & 1 & \text { Oktober } & 2017 .\end{array}$ administrasibisnis.studentjournal.ub.ac.id

Sartono, A. (2008). Manajemen Keuangan Teori dan Aplikasi. Edisi Empat. Yogyakarta: BPFE.

Salim HS dan Budi Sutrisno, 2008. Hukum Investasi di Indonesia. Penerbit PT Raja Grafinfo Persada : Jakarta.

Sari, Ni Putu Tila Permata. I Gusti Ayu Purnamawati dan Nyoman Trisna Herawati. 2017. Analisis Komparatif Saham LQ45 Sebelum Dan Sesudah Pilpres Amerika Serikat 2016. e-Journal S1 Ak Universitas Pendidikan Ganesha Jurusan Akuntansi Program S1 (Vol: 7 No: 1 Tahun 2017)

Sembel, Roy dan Totok Sugiharto. 2009. Kiat Berinvestasi Secara Nyaman dan Efisien Menuju Kemakmuran yang Membawa Berkat. PT Elex Media Computindo. Jakarta.

Situmorang, Paulus. 2008. Pengantar Pasar Modal. Edisi Pertama, Jakarta: Mitra Wacana Media

Sugiyono. (2017). Metode Penelitian Kuantitatif, Kualitatif, dan $R \& D$. Bandung: Alfabeta

Vibby, S. 2010. Jual Saham Anda Lebih Mahal, Edisi Kedua. Jakarta: Penerbit :Vibby Publishing

Waluyo, carolus Agus. 2018. Asian Games berpotensi jadi katalis positif bagi sektor consumer goods. www.kontan.co.id. Diakses pada tanggal 18 Juli 2018

Widayanto dan Sunarjanto. 2005. Analisis Pengaruh Pengumuman Pemecahan Saham (stock split) Terhadap Harga Saham, Volume Perdagangan Saham, Likuiditas Saham Yang Diukur Dengan Bid-Ask Spread pada Beberapa Perusahaan Go Public Di Bursa Efek Jakarta. Fokus Manajerial Vol. 3, No.2.

Wismar'ein, Dian. 2004. Reaksi Pasar Atas Pengumuman Right Issue Terhadap Abnormal Return Saham dan Likuiditas Saham (Studi Kasus Pada Bursa Efek Jakarta). Tesis. Program Pascasarjana Program Studi Magister Manajemen Universitas Diponegoro.

Yuwono, Andri. 2013. Reaksi Pasar Modal Di Bursa Efek Indonesia Terhadap Pengumuman Peristiwa Bencana Banjir Yang Melanda Daerah Khusus Ibu Kota Jakarta Tahun 2013. Jurnal Nominal/Volume II Nomor II/Tahun 2013 